Arab World English Journal (AWEJ) Volume 12. Number1 March 2021

DOI: https://dx.doi.org/10.24093/awej/vol12no1.28

Pp. 421-442

\title{
Uncovering New Paths to Adaptation: A Case Study of Malaysian English as a Second Language Pre-service Teachers
}

\author{
Taghreed El Masry \\ English and Literature Department, Al Israa' University \\ Gaza, Palestine \\ Corrsondent Author:nijim2@hotmail.com
}

Eman I Alzaanin

Faculty of Languages and Translation

King Khalid University

Abha, Kingdom of Saudi Arabia

Received : 12/23/2020 Accepted: 3/4/2021 Published: 3/24/2021

\begin{abstract}
This study aims to explore how English as a Second Language ESL Pre-Service Teachers (PSTs) employ adaptation strategies in response to the surrounding constraining context to develop their professional identities. The research question is "How do pre-service teachers (PSTs) employ adaptation strategies to develop their professional identity (PI) during their simulated teaching class and practicum?". Qualitative data were collected using semi-structured interviews and classroom observation from PSTs in a Malaysian university and public secondary schools in Kuala Lumpur. Findings showed that the positive notions of belonging to a Community of Practice $(\mathrm{CoP})$ proved to be applicable in the simulated teaching class context, so PSTs used their adaptation process of observation-experimentation and evaluation to attempt different teaching practices. Nonetheless, the positive notions of the CoP were inapplicable in the teaching practicum context. Hence, PSTs struggled to construct their Professional Identity (PI) and had to alter their adaptation strategies to negotiate PI construction. The study concludes with some recommendations for further use. Program designers need to consider social interaction and integration within the professional context. That could enable adaptation processes to enhance PSTs' PI development.
\end{abstract}

Keywords: Adaptation strategies, English as a second language, pre-service teachers, possible selves, professional identity

Cite as: El Masry, T., \& Alzaanin, E. I (2021). Uncovering New Paths to Adaptation: A Case Study of Malaysian English as a Second Language Pre-service Teachers. Arab World English Journal, 12 (1) 421-442. DOI: https://dx.doi.org/10.24093/awej/vol12no1.28 
Arab World English Journal (AWEJ) Volume 12. Number 1. March 2021

Uncovering New Paths to Adaptation: A Case Study of Malaysian

El Masry \& Alzaanin

\section{Introduction:}

Teacher Preparation Program (TPP) is crucial in PSTs' professional life (Grow, 2011). It provides the necessary environment for PSTs to translate theory into practice, to form a PI and to prepare them to move on smoothly to their future career as teachers (Friesen \& Besley, 2013; Harun, 2019). However, TPP still face the challenge of preparing PSTs to be effective teachers who are able to cope with the changing contexts of schools (Cooper \& He, 2012). Notably, PSTs find that moving from a university to a school context is a stage full of tensions and conflicts. Well-developed PI will serve as basis to handle and interact with the continuous changes in educational sites/policies (Afrianto, 2015).

Timoštšuk and Ugaste (2010), Ronfeldt and Grossman (2008) highlighted that learning to teach is experimental. While going through the simulated teaching and practicum stages, PSTs are offered different possible selves (i.e., teacher images and roles such as knowledgeable, compassionate, innovative, follower, conformer, etc.) to negotiate and from which to select what will be part of their core teacher identity or what to discard. Previous and recent literary work was sought to understand what factors contribute to, or hinder the process of teacher identity development (e.g., Kayi-Aydar, 2015; Khalid, 2014; Salinas \& Ayala, 2018) and student teachers' changing beliefs regarding the teaching profession during their teaching practice (e.g., Maaranen \& Stenberg, 2020; Van der Wal-Maris, Beijaard, Schellings, \& Geldens, 2019). However, rare are the studies that examined how PSTs experiment with their different possible selves during their teaching practice.

Trainees in different fields are expected to have adequate chances to "encounter, enact, and evaluate their possible selves" (Ronfeldt \& Grossman, 2008, p. 51), which would facilitate the process of developing professional identities despite the obstacles encountered in the practice setting. Nonetheless, the case of PSTs is complicated further. Ronfeldt and Grossman (2008) admitted that tensions in teacher preparation are greater due to the differences in value systems between what universities hope to prepare and what is expected at school sites. PSTs may not be given opportunities to try out possible selves and obtain good feedback to enable developing their professional identities (Hamman, Gosselin, Romano, \& Bunuan, 2010; Ronfeldt \& Grossman, 2008). Ronfeldt and Grossman (2008) contended that the PSTs' case still needs further investigation to express ideas and perceptions regarding professional identity development. Hence, the current study investigates how ESL PSTs adapt within the context of the journey of becoming teachers.

This study can contribute to PST's research by providing detailed descriptive accounts of how PSTs develop professional identities utilizing their adaptation processes (Izadinia, 2013). In addition, understanding PSTs' PI construction during TPP can better help program designers to base their programs on activities that enhance and support PI development at universities and practicum sites (Beijaard, Meijer, \& Verloop, 2004; Olsen, 2008). Researchers, such as Beijaard et al., 200; Izadinia, 2013 and Lerseth, 2013, argue that PSTs' PI development can directly impact PSTs' future decisions to join and remain in the teaching profession, as well as their practices and motivation to teach and seek development. Hence, focusing PSTs ' attention on the adaptation strategies on which they can rely to develop their identities can inform professional development programs. This study attempted to answer the following research question: 
Arab World English Journal (AWEJ) Volume 12. Number 1. March 2021

Uncovering New Paths to Adaptation: A Case Study of Malaysian

El Masry \& Alzaanin

How do pre-service teachers (PSTs) employ adaptation strategies to develop their professional identity (PI) during their simulated teaching class and practicum?

\section{Literature Review}

This study is framed by Cross and Markus' (1991) conceptions of possible selves and Ibarra's (1999) adaptation process. Cross and Markus (1991) proposed that possible selves are psychological resources (i.e., motivators and defendants of the now self) to explain the continuous changes across life. The social and cultural contexts around a person direct them to decide what selves to keep and develop, what selves to discard and for what selves to opt. Cross and Markus (1991) indicated that "in the process of successfully negotiating the changes and transitions, individuals must construct possible selves that help motivate toward desired ends and away from undesired outcomes" (p. 234). The possible selves are standards that help calibrate the professional identity to match personal and social context expectations (Ibarra, 1999).

Individuals handle any shifts and changes in their lives utilizing their adaptation process which represents the critical part of the cognitive development. Through the adaptation process, individuals experience new roles (here, possible selves) and encounter new knowledge upon changing sociocultural contexts. Their adaptation process can help them take in new knowledge, form new ideas and change existing one and adopt new behaviors that make them better prepared to deal with changes and complexities they face in the world around them (Berger, 2017).

An influential study that was conducted by Ibarra (1999) forms the basis of integrating a social and psychological approach to investigate PI construction within a CoP. Going through a cycle of trying out, revising and rectifying the possible selves can help construct new identities (Ibarra, 1999). As long as this process takes place within a Supported Community of Practice (SCoP), PSTs may have the chance to negotiate their identities to shift from a student to a teacher (Oruç, 2013).

Within the developmental framework of constructing PI in a SCoP, three adaptation strategies are investigated. Through the adaptation strategies of observation, experimentation and evaluation, Ibarra (1999) suggested that using the possible selves concept can guide novices to construct their own PI (Ronfeldt \& Grossman, 2008). Though it appears to be a linear process, the cycles are recursive as repetition will continue under the effect of one's experience within the social context (Ibarra, 1999) .

The first strategy of observation is aimed to build "a repertoire of possible selves." This repertoire is affected by student teachers' prior experience as school students, their experience with university courses and with the simulated teaching course and practicum stage (Chong, Ling, \& Chuan, 2011). The observation strategy includes two sub-strategies: (1) role prototyping and (2) identity matching. Novice practitioners observe professionals in action to learn more about role model traits. PSTs may have their supervisors, instructors, cooperating teachers and classmates teach in front of them. They can compare and contrast different teacher roles or practices to decide what role model to follow in their teaching. Once novices build role models, they decide on the feasibility, attractiveness and suitability of those roles to their own identities and personal traits (Ibarra, 1999). 
The second strategy is experimenting with possible selves, which may be provisional or transitional selves. Two types of strategies characterize this stage: (1) imitation and (2) true-toself strategies. Imitation strategies include (a) wholesale imitation, in which a learner copies the model style without much amendment. Imitation strategies also include (b) selective imitation, which implies being eclectic in selecting bits of identities from different models to create one's own style. Observing different role models including those of their supervisors, instructors, cooperating teachers and classmates may enable moving more confidently to selective imitation to create their own PI. True-to-self strategies are used next by learners to craft a provisional self that corresponds to their authentic personalities. The provisional self will "be refined with experience and internalized as enduring aspects of a coherent professional identity" (Ibarra, 1999, p. 778). Chou, Shen, Hsiao, Shen, and Shen (2019) contends that "self-adjustment affects the individual's response to the environment" (p.530), hence resulting in improving their teaching performance. Chou et al. (2019) reported in their study that "the pre-service teachers of the experimental group showed significant improvement in the areas of curriculum development and design, pro-teacher communication and professional leadership in the cross-disciplinary teaching specialization" (530).

At this stage, teacher educators need to be aware that exposing PSTs to 'existing routines' rather than 'new alternatives' may limit their growth. This may result in constructing a thin repertoire of selves (e.g., styles and tactics) to select from during the practice stage (Ronfeldt \& Grossman, 2008). Alelaimat, Ihmeideh, and Alkhawaldeh (2020) reported that their participants were dissatisfied "with their preparation for technology integration into classroom" (p. 299). They believed that they needed more exposure to innovating strategies to learn "more about technology integration in practice, and how to engage children in activities using technology and digital media" (p. 300). On the other hand, Ledger, Ersozlu, and Fischetti (2019) concluded in their study that exposing PSTs to "a high level of teaching quality" (p. 2) improved their selfefficacy to "plan, teach and assess" (p.2) their performance.

The last stage is evaluation using internal and external feedback (implicit or explicit) in the learning community to decide on an acceptable PI. Teacher educators and supervisors are recommended to handle this stage cautiously. Conformity to the practicum environment and the power authority within it may not construct the agents of change aspired by TPP (Fairbanks et al., 2010) .

Based on the previous discussion of Ibrarra's, Cross' and Markus' conceptions of possible selves and the adaptation cycle within the community of practice of TPP, Ronfeldt and Grossman (2008) provided a model depicting the different interfering elements within the SCoP in a TPP. More importantly, the model shows the three stages in the adaptation process that learners follow to advance in participation and develop their PI. It also indicates that learners repeat the cycle of interaction with the context, try possible selves and adjust provisional selves to craft their PI. This model will inform the findings presentation and discussion in this study. 


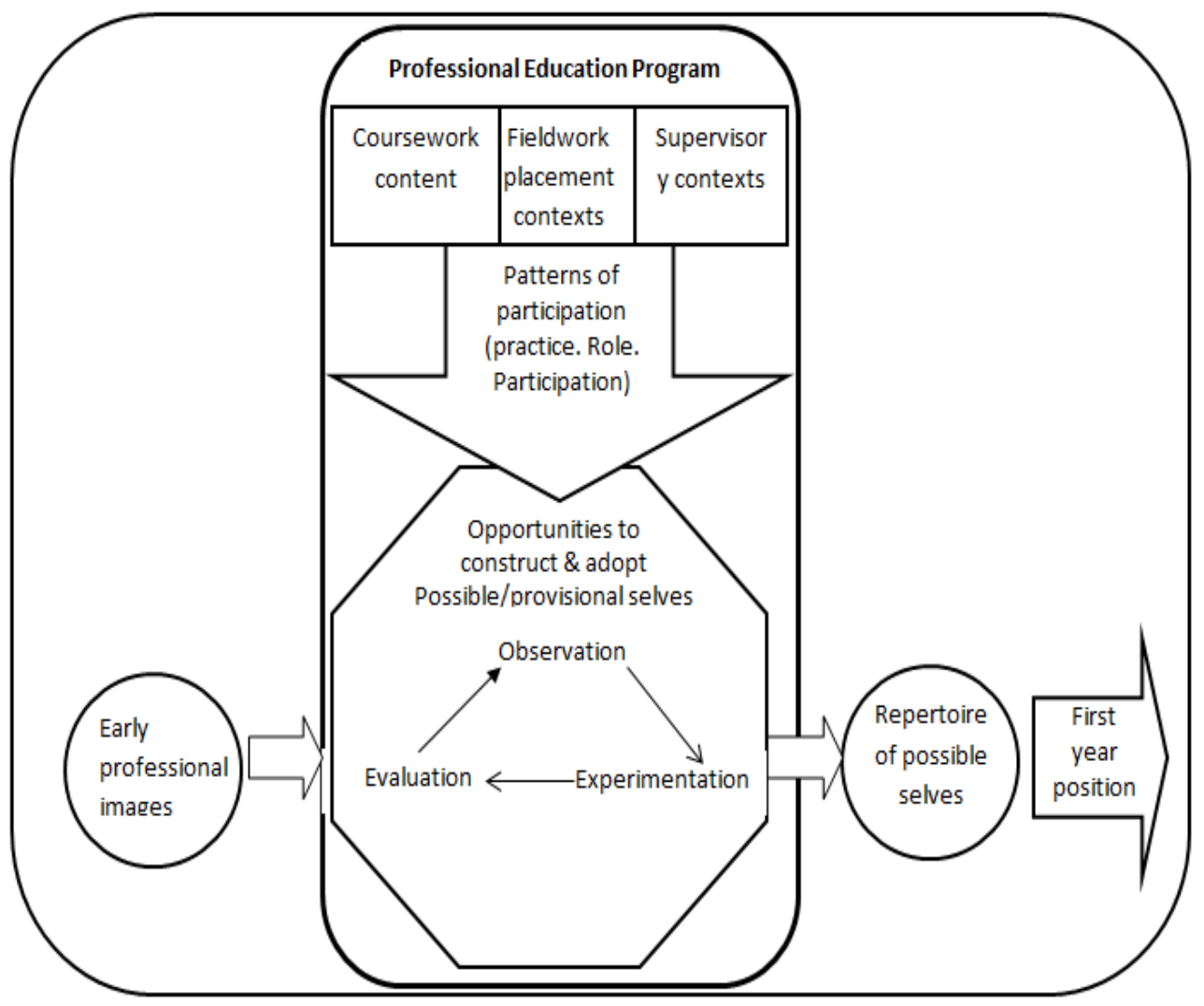

Figure 1. Professional Education Program and its Interfering Elements (Adopted from Ronfeldt and Grossman,2008, p. 43)

\section{Methodology}

Since the intention is to describe, understand and interpret (Merriam, 2009) the students' journey of constructing their identities as ESL teachers utilizing their adaptation processes, the qualitative case study is a more realistic lens for this research. The data gathered will lead to the emergence of theory (or model) construction, however crude it may be. That model corresponds to the peculiarities of the context and people studied since the research relies on the participants' views of the situation under study (Creswell, 2009).

\section{Participants}

In the educational context of Malaysia, the status of English is controversial, and this has led to many changes in educational policy, which swings between using English as a medium of education and diminishing it to merely a school subject (Darmi \& Albion, 2013). In an effort to cater to the needs of a multicultural and multiethnic population, the Malaysian Ministry of Education has formulated a philosophy of teacher education that emphasizes teacher quality (Jamil, Abd. Razak, Raju, \& Mohamed, 2011). Training colleges and universities are expected to prepare teachers to be able to realize the philosophy and survive the continuous curriculum changes (Malaysia Education Blueprint 2013 - 2025: Executive Summary, 2012). Teachers with a clear and solid professional identity can adapt to the tensions and turbulence occurring in the school context due to reforms imposed through the Malaysia visionary policy (Goh \& Matthews, 2011; Khalid, 2014). 
Arab World English Journal (AWEJ) Volume 12. Number 1. March 2021

Uncovering New Paths to Adaptation: A Case Study of Malaysian

El Masry \& Alzaanin

This study was conducted at a public research Malaysian university and public secondary schools in Kuala Lumpur. The TESL program integrates theoretical knowledge of English (skills and literature) with professional aspects (practical knowledge of classroom teaching practices). The program aims to prepare competent and skilled teachers in teaching English. Being good communicators in English with excellent social skills is another objective of the TESL program. Such skills could help PSTs negotiate their understanding and development in the professional context of the simulated teaching course, the practicum and future career.

From the end of the second year, PSTs are given three consecutive opportunities to link theory with practice. Firstly, they attend one week at a school of choice where they observe teachers teaching using various teaching strategies and class management techniques. Secondly, during the second semester of the third year, ESL PSTs join a simulated teaching class. Within the safe environment of the university, PSTs can transfer their theoretical knowledge about teaching methods and practices into a practical one. They engage in hands-on sessions to plan and implement lessons.

Thirdly, during the first semester of the fourth year, PSTs are placed in a secondary school, a real context where they work with real students under normal public-school conditions. Each class has about 32 students, including Malay, Chinese, Indian and a minority of other nationalities. PSTs are expected to teach 10 periods of English a week and two periods of a second method subject (moral class). TESL program's 'Guidelines for Teaching Practice' states that PSTs will have support from supervisors, mentor teachers, the principal and peers in school, who comprise the sociocultural context of the SCoP. Their actions, words and standards will direct how PST's PI is developing. The aims highlight creating a comfortable teacher-student relationship, improving PSTs' evaluating skills, building skills pertaining to extra-curriculum activities and building self-confidence. Most importantly, teaching practice is expected to enable them to observe and appreciate teachers' roles in class.

The 5 five participants were 22-24 years old, coming from different urban and rural areas around Malaysia. Participants were invited to sign a consent letter to participate in interviews and to be observed during their classes. Pseudonyms were used to preserve anonymity. Moreover, the schools where they practiced were also not named for confidentiality.

Table 1. Demographic information of participants

\begin{tabular}{lll}
\hline Participant Pseudonym & Age & Gender \\
\hline Aisha & 23 & Female \\
\hline Damia & 22 & Female \\
\hline Zara & 24 & Female \\
\hline Aida & 22 & Female \\
\hline Sophia & 23 & Female \\
\hline
\end{tabular}

Interview and classroom observation Interpretive researchers emphasize understanding the world through first-hand experience, truthful reporting and quotations of actual conversations from inside perspectives (Merriam, 2009). Hence, interview and classroom observation were the data generation methods because they are more likely to enable rich and detailed, or thick descriptions (Creswell, 2009; Yin, 2008) of the role of the social context and individual 
adaptation process in constructing PSTs' PI. These methods have the potential to encourage participants to speak freely about their lived experience regarding the phenomenon under study (Merriam, 2009).

The interview questions were piloted with two participants, Zara and Aida, who helped develop the questions to probe the participants' perceptions and thoughts more easily. Next, indepth one-to-one interviews were conducted, all of which were in English. The participants were interviewed three times during their simulated teaching class and three times during their practicum. Besides, they were observed while teaching twice in each stage. This strategy enabled researchers follow the developmental line of their PI construction and compare generated data with the study theoretical framework concepts.

\section{Constant Comparative Analysis Method}

Following Saldana (2009), the researchers utilized the constant comparative method using three major steps in data analysis: open coding (i.e., reading and identifying codes), focused coding (i.e., grouping the descriptive codes to develop categories) and theoretical or selective coding (i.e., identifying central interpretable themes in data).

\section{Findings}

Supported with substantial data, this section reports on how the five participants used personal adaptation strategies to respond to the opportunities or challenges they were exposed to during simulated teaching stage and school practicum.

\section{The Adaptation Cycle in the Simulated Teaching Context Facilitates PI Development}

The simulated teaching classes offered the PSTs a supportive community of practice with strong relationships to facilitate PI development. During this stage, the PSTs underwent three adaptation strategies to grow professionally: Observation, experimentation, and evaluation.

\section{Observation}

Observations of peers' model lessons enabled the participants to build a number of professional images pertaining to teacher character, teacher ability, teacher language performance, and classroom management. They felt well-guided during the microteaching observations because the supervisor provided an observation sheet to use as a reference. Aishah described liking Sophia's teacher's character when Sophia delivered her model lesson:

She was totally confident using her power point presentation of ideas and moving on the stage in front of us. Even when she missed explaining the activity to the learners, she didn't panic. She simply explained it and engaged her students again in the activity. She was enthusiastic and inspired us a lot.

Participants indicated that observing their peers' model lessons enhanced their teaching skills through exposure to different teaching strategies. Zara said she developed a repertoire of attention grabber strategies by observing her peers teaching: "I learned a number of strategies to arouse my students' interest in the lesson. I learnt to use a song, a short video or a photo". 
Arab World English Journal (AWEJ) Volume 12. Number 1. March 2021

Uncovering New Paths to Adaptation: A Case Study of Malaysian

El Masry \& Alzaanin

Damia stated that she learnt different techniques of giving feedback to her students by observing her peers' model activities: 'Observing my peers' strategies, I developed a number of feedback strategies".

Additionally, the participants reported improvement in their language performance by observing peer model lessons as well as improvement in using appropriate classroom language. Aisha commented that "I built a list of words and sentences to use during teaching. For example: Ok students let's open the book at page .... I found those sentences excellent to learn."

The PSTs also identified hated selves they would like to avoid in teaching. Aida expressed that she hated the strict image presented by one of her peers: "One of my peers was really strict while teaching. She didn't smile or show positive interaction with her learners.... I think this is a type of teacher that I would hate to become". Thus, the participants appreciated what they learnt about classroom pedagogy through observing simulated teaching classes. They found that observing their peers' classroom management techniques opened up horizons for thinking of different possibilities to choose from

\section{Experimenting with Different Possible Selves}

The second strategy the participants employed in developing a PI identity is selecting models from their repertoire of possible selves and trying them while teaching. Participants felt that their experimentation strategy was not to literally imitate a teacher model whom they had encountered previously. Instead, participants, such as Zara, reported selecting different possible selves from their repertoire to construct an appropriate synthesis to apply in their classes:

I thought that I can combine different practices, which I observed, in my lesson. For example, I picked Sophia's way of attention grabbing. The writing task, I picked from Aishah's class.

Ibarra (1999) defined three sub strategies of experimentation: wholesale imitation, selective imitation and true-to-self strategy. For our participants, selective imitation was a successful sub strategy to adopt, as they could select different possible selves to construct a well-synthesized lesson to apply in class. The participants also revealed that the selected professional images aligned with their own personalities. Zara found that her built teacher character was similar to her own personality as a cheerful person, while Aishah experimented with different possible selves and constructed her own style. Trying to teach apparently improved the PSTs' teaching performance and confidence in themselves as teachers; hence, they moved on to a higher step in the PI construction journey.

\section{Evaluation Using Internal and External Feedback}

The third adaptation strategy that PSTs used to develop a PI was to evaluate their teaching performance by using internal and external feedback. Evaluation strategy was vital for PSTs to assess and modify their pedagogical practice experimentation. The participants used self-evaluation to compare and contrast what they hoped to become as teachers and what they had become or practiced. Ibarra (1999) contended that congruence between individuals' selfconception of what they hoped to be and their practices can facilitate internalizing those practices (possible selves) to be part of self-representations. Our participants used their hoped-to-be selves as a reference for internal assessment. The participants evaluated their strengths and weaknesses 
Arab World English Journal (AWEJ) Volume 12. Number 1. March 2021

Uncovering New Paths to Adaptation: A Case Study of Malaysian

El Masry \& Alzaanin

and felt satisfied when their practices were in accordance with what they hoped to be. Damia revealed using such comparison and contrast to evaluate her teaching activities:

I tried to prepare my lessons and deliver them in a way I thought perfect for me as a teacher. I always wanted to be an innovative teacher. But while trying out teaching, I sometimes found that I didn't feel comfortable using technology in class. For example, I wasted five minutes to adjust the volume. I didn't show the innovative person I wanted.

For Aishah, self-evaluation enabled her to realize her strengths and weaknesses:

I hoped to be a compassionate teacher. I admired my previous teachers who built good relationships with us. I wanted to be like them. Then, on my first lesson, I found myself unable to create such rapport with my students.

At the end of the simulated teaching session, the participants reported a high sense of PI. Sophia believed that she achieved the self she chose, "I'm satisfied with what I achieved here. I wanted to be an innovative, enthusiastic and active teacher and I became what I wanted".

In summary, the adoption, alteration and rejection of various possible selves were all found in the interview data. The participants believed they modified their professional images to match their observers' expectations, which helped them grow as teachers. When the PSTs had adequate opportunities to observe, try out and get feedback on their teaching performance, they succeeded in developing a confident and motivated PI.

\section{Altering Adaptation Strategies in the Challenging Teaching Practicum Context}

As the PSTs moved from the simulated teaching classes at university to the real classroom context at public secondary schools, they began encountering a number of difficulties and tensions. The PSTs reported being sent alone to class with no support or guidance on how to solve the problems faced. The participants discovered that the adaptation strategies of observation, experimentation, and feedback utilized during the simulated teaching classes were not applicable at the practicum sites. Hence, the participants exerted efforts to adapt to the constraints faced in PI development by deliberately replacing the observation-experimentationevaluation cycle with new mechanisms to overcome the PI crisis.

\section{Responding to Inadequate Observations via Images from Prior Experience \& Imagined Images}

The participants apparently had very limited access to practical knowledge at the practicum sites. Their mentors and peers were overloaded with burdens; hence, the participants could not exchange regular visits with peers and mentors. To respond to lack of observation opportunities, the participants employed images from prior experience and imagined pictures of their mentors and peers based on unseen observations to guide PI construction.

Recalling pre-constructed possible teacher selves was one of the PSTs' means of developing their PI and mitigating the challenges they encountered at the real classrooms. They used prior experience to respond to their students' lack of interest and motivation. Aida used her recollection of her role model teacher to face her own students' lack of motivation to learn: 
My form four (10th grade) English teacher used interactive activities. She was enthusiastic, encouraging, and altered her teaching styles to suit the students. I loved her classes because they were energetic and full of life. I used this memory to motivate me create different activities to encourage my students to come to class. It took me great effort and time, but eventually the strategy succeeded.

Additionally, the participants reported that their prior experience stimulated them to consider having closer relationships with their students as a strategy to overcome classroom management problems. Zara considered the memory of her Form four grade teacher a reason for her to work towards building rapport with her students to face classroom disorder:

My teacher was compassionate and had great relationships with us. She always encouraged students to articulate their ideas. I decided to use her strategy to handle my students' discipline problems. When I became friends with them and maintained my authority at the same time, I managed to convince them to listen to me. Now when I call their names, they listen to me. Not always....

The findings highlighted the power of memories on PSTs' practice and the value of recalled memories in guiding PSTs' development in the absence of live professional images.

The second mechanism employed by the PSTs in the current study to compensate for the absence of mentors and peers from their classes was to construct imagined images based on talks with mentors or peers outside class. The participants reported having limited opportunities to see their mentors outside classes. These opportunities helped participants build imagined images of their mentors in action. Damia, for example, referred to such imagined images as a way to construct new professional images on which to caliber her practice:

When my mentor explained to me how she taught a speaking activity, I'd imagine that. When I go to my class, I keep this memory alive in front of my eyes and I start teaching using those imagined images. This strategy helped me a lot since I couldn't go to observe my mentor's classes.

Participants also reported seeking peers' suggestions on how to manage classes. Through those suggestions, participants constructed images of their peers in action. Zara found that her peers' suggestions helped her handle noisy students:

I found my students very noisy, so I asked my peer trainees what I should do there. They gave me very useful suggestions....

\section{Experimenting Alone in Class}

Participants reported they could not escape the fact of working alone in their classes. They revealed struggling with classroom management and lesson plan execution. The participants expressed they felt insecure, confused and unguided in their classes. They believed that the absence of their mentors encouraged students to take advantage of the PSTs. Moreover, the participants believed they were inadequately supported, which led to a professional identity crisis. To overcome this PI crisis, they attempted different teaching strategies that helped them 
eventually gain PI awareness and understand their strengths and weaknesses. PSTs used two strategies to adapt to the challenging context: selective imitation and modified practices.

According to the participants, they started teaching at the practicum sites using the practical knowledge gained through microteaching in the simulated teaching classes. Soon, they discovered that the simulated teaching context differed from the realistic context of secondary schools. Aida mentioned that she experimented with many teaching strategies that she either practiced or observed in her simulated teaching classes:

I tried out different strategies in my classes, such as an inductive strategy of teaching grammar. I prepared educational games similar to those we prepared for simulated teaching.

The current study findings reveal that the participants decided to follow another strategy (modified practices) to amend practices and behaviors in response to their students' interests. When Aida noticed that her students liked to express ideas in debating activities, she engaged them more in such activities:

I found out how much my students liked debating. I think it's their nature as they are very active and all the time, they object to whatever they don't like. I started to try out more debating activities and I think they enjoyed that a lot.

Zara attempted calling students by their names. That reflected positively on her relationship with them, and consequently affected her classroom management.

Such discoveries evidently enabled PSTs to regain confidence and make progress in PI development.

\section{New Mechanisms of Evaluation and Feedback}

Not exchanging observation visits with peers and mentors on the practicum sites deprived participants of receiving adequate and constructive feedback. Instead, they had to alter their feedback sources to respond to the lack of mentor and peer feedback. They adopted an internal feedback strategy and altered the external feedback strategy to include mentor and peer feedback based on unseen observation and students' nonverbal and verbal feedback.

The first mechanism available for the participants to evaluate their practices was their internal feedback based on their possible selves' repertoire (prior images and personal standards). Damia, for example, used her role model teacher images to judge to what extent her practices were good, "Comparing what I do to what my teachers did in our secondary school classes was the first strategy that I relied on to assess my work." Aida believed she used her standards to evaluate her own teaching performance: "I used my hoped-to-be self to judge my practices and behavior in my classes. That helped me a lot to amend my teaching practices and character to match my hoped-to-be self and to avoid my feared-to-be self. "

As the participants faced more difficulties in their classes, they believed internal feedback was not sufficient. However, external feedback during classroom practicum was not as effective as when used during the simulated teaching classes. The participants sought their 
mentors and peers' comments outside class. They would try to take a few minutes from their mentors' time to describe the lessons taught by the participants and get the mentors' evaluation and suggestions for improvement. Damia took advantage of assembly time to consult her mentor:

During the assembly time, I would take five minutes talking to my mentor. I tell her what happened with me in my lesson the previous day. She would tell me what was good and what I could do better. Her comments helped me.

Aida took advantage of the shifting time between classes to seek her mentor's feedback, "If I saw my mentor around during the shifting between classes, I would hurry to her and tell her what I taught the other day and get her comments".

In their evaluation, the mentors relied on what the PSTs chose to report within a very limited time. Participants believed this kind of feedback was inadequate and did not reach their standards of what feedback represented. Our participants felt lost and isolated and suffered a PI crisis in the absence of such influential feedback. Consequently, they attempted to secure some constructive feedback from peers. They reportedly saw their peers more in the staff room or during extracurricular activities to obtain feedback on their performance. Zara talked about her class with a peer to help sort out what was wrong that led to so much noise in Zara's class:

I described my lesson to Aishah and the others. In that lesson, I used group work with my students, but I ended up with much noise and fights. My friends commented that my instructions were not clear for my students and that was why they felt angry. I developed my group activity instructions for the next class and that worked better.

Practicing under such challenging practicum conditions, the participants considered their school students as the third resort for seeking feedback. At the beginning, the participants relied mainly on students' nonverbal reactions to decide whether their teaching strategy or behavior was appropriate. Nonverbal reactions guided participants' teaching performance in terms of adopting, discarding or modifying teaching practices as needed. Similar to the other participants, Aishah relied on her students' nonverbal reactions to caliber her teaching strategies:

I look at the students. If they show they understood and they were interested in my lesson, then I'd say it was a good lesson. But if they were bored, it would be a sign that the lesson wasn't well-done.

Later, the participants decided to act deliberately and obtain their students' oral or written feedback. Aida sought her students' oral comments on her classes; Zara asked her students to write comments on paper. These findings demonstrate that the PSTs managed to understand their students' needs, build good rapport with them, and most importantly, manage classroom problems to a good extent. Despite the depletive role of the students in participants' professional growth journey, it seems that students were a motivating and supportive factor in 
Arab World English Journal (AWEJ) Volume 12. Number 1. March 2021

Uncovering New Paths to Adaptation: A Case Study of Malaysian

El Masry \& Alzaanin

participants' PI construction. Participants worked hard to come up with activities and procedures that would help gain students' friendship and attention.

To sum up, though participants' opportunities to experiment and receive feedback in the practicum context were limited, they managed to amend their adaptation strategies to respond to the challenges. By the end of the practicum, they achieved a new shift in their PI towards PI awareness by leaving the PI crisis, which they experienced due to a lack of guidance and support with practicum teaching. They became more aware of their strengths and weaknesses.

\section{Discussion}

As reported in the findings above, the simulated teaching classes offered the PSTs a supportive community of practice with strong relationships to facilitate PI development. Beauchamp and Thomas (2009, p. 177) argued that PI is "a constantly evolving phenomenon involving both a person and a context." Since the contextual factors were facilitative of PI development in the simulated teaching classes, the PSTs underwent three adaptation strategies to grow professionally. The first strategy, observation, had two main outcomes: building professional images and matching identities to build one's style. This finding supports those of Ogeyik's (2009) where 57 ELT PSTs in a Turkish university benefited from observing peers' model lessons by promoting the PSTs' effective teaching strategies. Similarly, Benton-Kupper (2001) rightly recognized that peer observation was beneficial and helped PSTs learn about the teaching craft. The current study is also consistent with Ismail's (2011) study as it provides empirical evidence that observing peers' model lessons can enhance the participants' language skills in terms of using appropriate classroom language, correct pronunciation and a clear voice. Since the adaptation cycle is iterative (Ibarra, 1999; Ronfeldt \& Grossman, 2008), an individual tries out learned practices and then observes others in professional roles to match identities between oneself and the others. PSTs construct tentative images through apprenticeship of observation (Lortie, 1975) during their educational experiences while observing teachers (at school and university) teaching.

Experimentation was the second adaptation strategy PSTs adopted in trying various possible selves to develop their PI. The participants referred to the possible selves they constructed while observing their peers' model lessons as a vivid source for trial. This finding aligns with the participants in Ronfeldt and Grossman's (2008) study who reported that the different PI models encountered in their TEP were valuable for them to attempt themselves. Maria L. Fernandez and Robinson (2006)The third adaptation strategy that PSTs used to develop a PI was to evaluate their teaching performance by using internal and external feedback. The participants used self-evaluation to compare and contrast what they hoped to become as teachers and what they had become or practiced. Ibarra (1999) contended that congruence between individuals' self-conception of what they hoped to be and their practices can facilitate internalizing those practices (possible selves) to be part of self-representations. According to the participants, they used their hoped-to-be selves as a reference for internal assessment The value of the internal feedback mechanism is understudied in literature, whereas focus is on the value of external feedback (Britton \& Anderson, 2010; Maria Lorelei Fernandez, 2010; Maria L. Fernandez \& Robinson, 2006; Ismail, 2011; Korkko, KyroAmmala, \& Turunen, 2016; Ogeyik, 2009; Ronfeldt \& Grossman, 2008). 
Arab World English Journal (AWEJ) Volume 12. Number 1. March 2021

Uncovering New Paths to Adaptation: A Case Study of Malaysian

El Masry \& Alzaanin

Furthermore, external feedback from supervisors and peers effectively influenced PSTs' PI development. Observing others' practices and trying out different possible selves may not be as effective without immediate and constructive feedback from those observing PSTs in action. Such feedback helps novices to correct practices and underlying conceptions of those practices (Ibarra, 1999; Ismail, 2011; Ronfeldt \& Grossman, 2008). The feedback offered by SCoP members enabled participants to adopt, modify or discard teaching strategies based on positive or negative feedback on their teaching performance. Britton and Anderson's (2010) study is in agreement with the fact that PSTs alter their pedagogical practices based on peer feedback.

The participants in the current study reported readiness to receive feedback from peers and supervisors. They revealed they were open-minded to others' comments and sought even more help to grow professionally. In contrast, Amobi (2005) studied the reflective journals of 31 PSTs during their microteaching classes. Apparently, the PSTs were defensive and passive towards their peers' comments because they felt their peers were competitive and unfair in their evaluation. The argument is that the presence of a facilitating supervisor helps PSTs imagine how negotiating with peers and reacting positively to their feedback may promote professional growth (Wenger, McDermott, \& Snyder, 2002).

Similar findings on the value of immediate feedback from supervisors and peers were reported by Korkko et al. (2016), who emphasized that such feedback needs to be constructive. Korkko et al. thematically analyzed 13 PSTs' reflective journals to investigate how external feedback resulted in the development of the PSTs' practical theories. Korkko et al.'s (2016, p. 202) study demonstrated that "the feedback and dialogical reflections with their supervisors and peers provided a learning opportunity to further develop their practical theories" (p. 202). Constructive feedback is necessary for PSTs to learn how they act and explore the underlying assumptions or preconceptions behind these actions (Beijaard et al., 2004)

As the PSTs changed contexts by moving from the simulated teaching classes at university to the real classroom context at public secondary schools (i.e., practicum sites), they began encountering a number of difficulties and tensions caused by socio-contextual factors. The PSTs reported being sent alone to class with no support or guidance on how to solve the problems faced. The participants discovered that the adaptation strategies they used during the simulated teaching classes were not practical at the practicum sites. Hence, the participants exerted effort to adapt to the constraints faced in PI development by altering the observation-experimentation-evaluation cycle. They deliberately added new mechanisms to overcome the PI crisis.

The participants recalled prior experience of learning from their secondary school teachers' practices to teach and manage classes. They referred to their model teachers' images in adopting their practices in class and for classroom management techniques. PSTs' reactivating educational memories of school and university teachers to create visions of desired teacher selves echoes Flores and Day's (2006) and Cook's (2009) findings. More recently, Miller and Shifflet (2016) analyzed the reflective journals of 69 PSTs who were asked to write about their school memories and reflect on the meanings. Their participants 
Arab World English Journal (AWEJ) Volume 12. Number 1. March 2021

Uncovering New Paths to Adaptation: A Case Study of Malaysian

El Masry \& Alzaanin

claimed those memories enabled them to create their desired selves. They also recognized some conflict between memories and sound teaching practices they learnt during the TEP. The findings indicated the power of memories on PSTs' practice with teaching. The current study findings support the value of recalled memories in guiding PST development in the absence of live professional images.

The second mechanism employed by the PSTs in the current study to compensate for the absence of mentors and peers from their classes was to construct imagined images based on talks with mentors or peers outside class. Unseen observation and its role in building imagined professional images has not been reported in literature on PSTs. Only one study by Ronfeldt and Grossman (2008) with a number of novices resonates with the current study findings pertaining to imagined professional images. The researchers noted that their clinical psychology PST, Quise, had a high opinion of her mentor, as the kind of clinical psychologist Quise hoped to become. She described her mentor with positive qualities as kind, confident and competent. Quise admitted she had almost no chance to observe her mentor in real practice. The researchers concluded that their participants "were often making inferences based on what they imagined rather than what they observed" (Ronfeldt \& Grossman, 2008, p. 47).

Teaching classes alone, the participants reported struggling with classroom management, which affected their teaching performance negatively. They felt unconfident, confused, unguided and burnt out at the practicum sites. Despite the absence of observers (i.e., mentors or peers), the participants kept trying different teaching strategies and solutions to eventually gain PI awareness. They employed two mechanisms of experimentation: selective imitation during the simulated teaching classes, and modified practices as solutions to the challenging context. As discussed earlier for the observation strategy, the participants found previous images as sources of more feasible practices to try in the secondary school context. This strategy helped them overcome the lack of resources and educational aids at the practicum sites. The participants sometimes faced difficulties when trying out practices that were appealing to them as students. Some of the practices were not welcome by current students. It is argued that when PSTs recall memories to help accept or reject certain strategies, they base their judgment on what worked and was suitable with their current students (Castañeda, 2014; Fairbanks, Freedman, \& Kahn, 2000; Miller \& Shifflet, 2016).

The study findings regarding PSTs' journey through the teaching practicum indicate they were unguided and unsupported, which resulted in a PI crisis. Halfway through making sense of their journey, the participants declared they started to find their own ways to improve their practices and adjust to the challenging secondary school context. Not exchanging observation visits with peers and mentors also deprived them of receiving adequate and constructive feedback. According to the participants, they had to alter their feedback sources to respond to the lack of mentor and peer feedback. They adopted an internal feedback strategy and altered the external feedback strategy to include mentor and peer feedback based on unseen observation and students' nonverbal and verbal feedback.

From the participants' perspective, internal feedback was not as effective as when used during the simulated teaching classes. According to the findings, the participants sought 
Arab World English Journal (AWEJ) Volume 12. Number 1. March 2021

Uncovering New Paths to Adaptation: A Case Study of Malaysian

El Masry \& Alzaanin

their mentors and peers' comments outside class. The participants could not devote much time for such feedback, as they had only few minutes to talk to their mentors. Ronfeldt and Grossman (2008) noted that PSTs had opportunities to try out teaching strategies, but they received little evaluation. Without meaningful and constructive feedback, whether oral and face-to-face or written, novices cannot judge whether their practices are up to professional standards and achieved the learning outcome (Ali \& Al-Adawi, 2013; Ronfeldt \& Grossman, 2008). Constructive feedback can motivate PSTs and encourage them to exert more effort on improving their teaching performance (Ali \& Al-Adawi, 2013; Copland, 2010, 2011; Davis \& Dargusch, 2015; Hattie \& Timperley, 2007; White, 2007).

The result from the current study that PSTs could not secure meaningful feedback from mentors contradict with many other studies that investigated the types and value of feedback the participants received. For example, White's (2007) PSTs participants from New Zealand revealed that oral feedback from their mentors was given most often and was the most useful mode of feedback. Owing to such effective modes of feedback they were able to focus and direct their teaching practices and professional growth. In a similar vein, Ali and Al-Adawi (2013). conducted a study with Omani EFL PSTs of the type and value of practicum feedback. The majority of participants perceived practicum feedback, whether written or spoken, positively. Unlike White's (2007) participants who preferred spoken feedback, Ali and Al-Adawi's PSTs considered written feedback as more effective than oral feedback, because they could refer to it any time and that improving PSTs' pedagogical skills and knowledge. Feiman-Nemser (2001, p. 23) postulated that concrete and constructive feedback enables PSTs to "visulaize their evolving style, clarify what they need to work on, and concretize their own vision of good teaching" (p. 23). In contrast to the participants in the two aforementioned studies, those in the current study felt lost and isolated, and suffered a PI crisis in the absence of such influential feedback.

In the current study, the participants claimed that the feedback received from their mentors was inadequate and inappropriate. Consequently, they attempted to secure some constructive feedback from peers. They met peers more in the staff room, thus having a better chance to get feedback on their performance based on their descriptions of their classes. In the literature, direct observation of peers' lessons and immediate feedback proved to be more fruitful (Anderson, Barksdale, \& Hite, 2005; Feiman-Nemser, 2001). One of the findings in Anderson et al.'s (2005) study is that the PSTs expanded peer observation and feedback from once weekly as required by the TEP, to a daily basis. They believed this strategy to be effective in enhancing their pedagogical and classroom management skills. Another study conducted by Starkey and Rawlins (2011) in New Zealand revealed that $90 \%$ of PST participants reported finding peer feedback (face-to-face feedback during staff room discussion) influential and supportive along their teaching practicum journey. About $70 \%$ of PSTs found informal face-to-face feedback from peers more effective than formal university organized sessions (15\%). The researchers recommended that PSTs exchange more constructive feedback with peers using different social networking tools such as Facebook or Twitter. This can help PSTs, for instance in the current study context, to compensate for the minimal opportunities available at the practicum sites to meet and reflect on their practices. 
Practicing under such challenging practicum conditions, the participants kept attempting to obtain feedback that could direct and give them a sense of achievement during the practicum. This study shows that the participants considered their school students as the third resort for seeking feedback. These findings demonstrate that the PSTs managed to understand their students' needs, build good rapport with them, and most importantly, manage classroom problems to a good extent. Many studies reported that building rapport with school students soothed PSTs' tensions and increased their motivation to work harder in class (Shafer, 2015; Sueb, 2013). However, those studies did not refer to PSTs' deliberately seeking students' verbal or nonverbal feedback to improve their teaching skills. Sueb (2013) and Shafer (2015) reported only that their PSTs tried to resolve the challenges with students' misbehavior and lack of motivation by creating fun activities, memorizing the students' names, punishing negative behaviors and rewarding positive ones, and becoming friendly with students.

This research contributes to current knowledge on language teacher professional identity by proposing alterations to Ibarra's (1999) adaptation cycle of observationexperimentation and evaluation to respond to the contextual challenges. Ibarra's adaptation cycle proved to be applicable to the simulated teaching class SCoP. The PSTs had the opportunity to engage in interactions and negotiations with the other SCoP members and work on developing their PI using their adaptation strategy extensively. However, the study findings proved that Ibarra's (1999) model, which was adopted by Ronfeldt and Grossman (2008), was impracticable when the PSTs were confronted with the challenging teaching practicum context. Because they felt isolated and alone in classes with no guidance, feedback or support, the PSTs altered their adaptation strategies and created others to manage PI crisis. Hence, the study contributes to literature by adding new adaptation strategies to Ibarra's cycle to respond to challenging contexts. Table (2) shows the applicability and alterations of Ibarra's model of the adaptation cycle in the current study context. Three symbols serve to show if the strategy in Ibarra's (1999) adaptation model was applicable in the study context $(\sqrt{ })$ or if the strategy was not applicable $(X)$. The table also shows what new strategies were added to replace strategies in Ibarra's adaptation cycle model (+).

Table 2. Applicability and alterations of Ibarra's (1999) model in the current study context

Supportive context of simulated Challenging context of teaching teaching class practicum

\begin{tabular}{|c|c|c|}
\hline Adaptation cycle & Applicable & Inapplicable \\
\hline observation & $\begin{array}{l}\text { Observing and being observed in the SCoP } \\
\sqrt{ } \text { Built professional images. } \\
\sqrt{ } \text { Matching identities to build one's style }\end{array}$ & $\begin{array}{l}\text { No observation then reverted to } \\
+ \text { Images from prior experience } \\
+ \text { Imagined images of mentors and peers } \\
\text { based on unseen observation. }\end{array}$ \\
\hline Experimentation & $\begin{array}{l}\text { Experimenting in the presence of } \\
\text { supervisor and peers } \\
\sqrt{ } \text { Selective imitation of others' } \\
\text { performance } \\
\sqrt{ } \text { True-to-self strategy } \\
X \text { Wholesale imitation }\end{array}$ & $\begin{array}{l}\text { Experimenting alone in classes } \\
\sqrt{ } \text { Selective imitation of previously } \\
\text { constructed images } \\
+ \text { Modified practices to suit students' } \\
\text { interests }\end{array}$ \\
\hline Evaluation & $\begin{array}{l}\text { Adequate and constructive feedback } \\
\sqrt{ } \text { Internal (based on one's standards) } \\
\sqrt{ } \text { External feedback (from supervisor and }\end{array}$ & $\begin{array}{l}\text { Absence of adequate and constructive } \\
\text { feedback } \\
\sqrt{ } \text { Internal (based on prior images and }\end{array}$ \\
\hline
\end{tabular}


Arab World English Journal (AWEJ) Volume 12. Number 1. March 2021

Uncovering New Paths to Adaptation: A Case Study of Malaysian

El Masry \& Alzaanin

peers)

personal standards)

+ External feedback (mentors and peers

based on PSTs' description of their

lessons).

+ Students' nonverbal and verbal feedback

Key of symbols- $(\sqrt{ })$ : strategy in Ibarra's (1999) model is applicable; $(X)$ : strategy in Ibarra's (1999) model is not applicable; (+) new strategy that replaced Ibarra's (1999) model strategies.

This study recommends that program designers need to recognize how to enable adaptation processes to enhance PSTs' PI development. There should be more focus on social aspects in building teacher preparation programs. Besides focusing on individual teacher's tasks in teaching, more value should be given to social interaction and integration within the professional context. Perspectives of collegial and mutual relationships between PSTs and mentors, supervisors, peers and other teachers could help inform identity construction positively. In addition, PSTs should be taught about the self as a teacher (Alsup, 2006) and the possible adaptation strategies that could mitigate the impact of the constraining contexts upon PST professional identity development during practicum.

\section{Conclusion}

The study was aimed at exploring the way five Malaysian ESL PSTs employed adaptation strategies during the simulated teaching class and teaching practicum stage to respond to contextual affordances or challenges in developing their PI. This study demonstrated how PSTs develop a sense of professional identity through their simulated teaching classes at university and student teaching practicum. The positive notions of belonging to a community of practice (i.e., collaboration, mutual and collegial relationships) prove to be applicable in the simulated teaching class context. In such a supportive training context, PSTs use their adaptation process of observation-experimentation and evaluation to attempt different teaching practices. Nonetheless, the positive notions of the community of practice are inapplicable in the teaching practicum context. Hence, PSTs struggle to construct their PI and negotiate their understanding and teaching practices. PSTs must alter their adaptation processes to find other strategies to negotiate PI construction.

\section{About the Authors:}

Taghreed El Masry is an assistant professor of Applied Linguistics at the English and Literature Department at Al Isra' University. Her areas of interest are teacher education, teaching English as a second language, teacher identity, curriculum design and assessment.

ORCID https://orcid.org/0000-0002-1201-6371

Eman Alzaanin is an assistant professor of Applied Linguistics in the English language program at the Faculty of Languages and Translation - King Khalid University. Her areas of interests include language pedagogy and teacher education, teacher emotion, curriculum design, and program evaluation. ORCID https://orcid.org/0000-0001-9332-233X

We have no known conflict of interest to disclose. 
Arab World English Journal (AWEJ) Volume 12. Number 1. March 2021

Uncovering New Paths to Adaptation: A Case Study of Malaysian

El Masry \& Alzaanin

\section{References}

Afrianto, A. (2015). Constructing professional identity through teaching practicum: an Indonesian case study of pre-service English teachers. Monash University. Faculty of Education,

Alelaimat, A. M., Ihmeideh, F. M., \& Alkhawaldeh, M. F. (2020). Preparing Preservice Teachers for Technology and Digital Media Integration: Implications for Early Childhood Teacher Education Programs. International Journal of Early Childhood, 52(3), 299-317. doi:10.1007/s13158-020-00276-2

Ali, H. I. H., \& Al-Adawi, H. A. (2013). Providing Effective Feedback to EFL Student Teachers. Higher Education Studies, 3(3), 21.

Alsup, J. (2006). Teacher identity discourses: Negotiating personal and professional spaces. Mahwah, NJ: Lawrence Erlbaum.

Amobi, F. A. (2005). Preservice teachers' reflectivity on the sequence and consequences of teaching actions in a microteaching experience. Teacher Education Quarterly, 32(1), 115-130.

Anderson, N. A., Barksdale, M. A., \& Hite, C. E. (2005). Preservice teachers' observations of cooperating teachers and peers while participating in an early field experience. Teacher Education Quarterly, 32(4), 97-117.

Beauchamp, C., \& Thomas, L. (2009). Understanding teacher identity: an overview of issues in the literature and implications for teacher education. Cambridge Journal of Education, 39(2), 175-189. Retrieved from http://www.tandfonline.com/doi/abs/10.1080/03057640902902252

Beijaard, D., Meijer, P. C., \& Verloop, N. (2004). Reconsidering research on teachers' professional identity. Teaching and Teacher Education, 20(2), 107-128. Retrieved from http://www.sciencedirect.com/science/article/pii/S0742051X04000034

Berger, K. S. (2017). The developing person through the life span (10th ed.). New York, NY: Worth Publishers

Britton, L. R., \& Anderson, K. A. (2010). Peer coaching and pre-service teachers: Examining an underutilised concept. Teaching and Teacher Education, 26(2), 306-314.

Castañeda, J. A. F. (2014). Learning to Teach and Professional Identity: Images of Personal and Professional Recognition. Profile Issues in Teachers`Professional Development, 16, 4965. Retrieved from http://www.scielo.org.co/scielo.php?script=sci_arttext\&pid=S1657$07902014000200005 \&$ nrm $=$ iso

Chong, S., Ling, L. E., \& Chuan, G. K. (2011). Developing Student Teachers' Professional Identities- An Exploratory Study. International Education Studies, 4(1), 30-38.

Chou, C.-M., Shen, C.-H., Hsiao, H.-C., Shen, T.-C., \& Shen, T.-C. (2019). Self-adjusting Learning Strategies of Preservice Teachers' Cross-disciplinary Teaching Professionalization: Adjusting 107 Curriculum Reform and Industry 4.0. International Journal of Information and Education Technology, 9(8).

Cook, J. S. (2009). "Coming into my own as a teacher": Identity, disequilibrium, and the first year of teaching. The New Educator, 5(4), 274-292.

Cooper, J. E., \& He, Y. (2012). Journey of "Becoming": Secondary Teacher Candidates' Concerns and Struggles. Issues in Teacher Education, 21(1), 89-108. Retrieved from http://search.proquest.com/docview/1243100600?accountid=28930 
Arab World English Journal (AWEJ) Volume 12. Number 1. March 2021

Uncovering New Paths to Adaptation: A Case Study of Malaysian

El Masry \& Alzaanin

Copland, F. (2010). Causes of tension in post-observation feedback in pre-service teacher training: An alternative view. Teaching and Teacher Education, 26(3), 466-472. doi:http://doi.org/10.1016/j.tate.2009.06.001

Copland, F. (2011). Negotiating face in feedback conferences: A linguistic ethnographic analysis. Journal of Pragmatics, 43(15), 3832-3843.

Creswell, J. W. (2009). Reseach design: Qualitative, quantitative and mixed methods approaches (3rd ed.). California: SAGE Publications, Inc.

Cross, S., \& Markus, H. (1991). Possible Selves across the Life Span. Human Development, 34(4), 230-255. Retrieved from http://www.karger.com/DOI/10.1159/000277058

Darmi, R., \& Albion, P. (2013). English language in the Malaysian education system: Its existence and implications. Paper presented at the 3rd Malaysian Postgraduate Conference (MPC2013), New South Wales, Australia.

Davis, S. E., \& Dargusch, J. M. (2015). Feedback, iterative processing and academic trustteacher education students' perceptions of assessment feedback. Australian Journal of Teacher Education, 40(1), 10.

Fairbanks, C., Duffy, G., Faircloth, B., He, Y., Levin, B., Rohr, J., \& Stein, C. (2010). Beyond Knowledge: Exploring Why Some Teachers Are More Thoughtfully Adaptive Than Others. Journal of Teacher Education, 61(1-2), 161-171. doi:10.1177/0022487109347874

Fairbanks, C., Freedman, D., \& Kahn, C. (2000). The role of effective mentors in teaching to learn. Journal of Teacher Education, 51(2), 102-112.

Feiman-Nemser, S. (2001). From Preparation to Practice: Designing a Continuum to Strengthen and Sustain Teaching. Teachers College Record, 103(6), 1013. Retrieved from http://search.ebscohost.com/login.aspx?direct=true \&db=aph\&AN=5528902\&site=eds$\underline{\text { live }}$

Fernandez, M. L. (2010). Investigating how and what prospective teachers learn through microteaching lesson study. Teaching and Teacher Education, 26(2), 351-362.

Fernandez, M. L., \& Robinson, M. (2006). Prospective teachers' perspectives on microteaching lesson study. Education, 127(2), 203-216.

Flores, M. A., \& Day, C. (2006). Contexts which shape and reshape new teachers' identities: A muti-perspective study. Teaching and Teacher Education, 22(2), 219-232.

Friesen, M. D., \& Besley, S. C. (2013). Teacher identity development in the first year of teacher education: A developmental and social psychological perspective. Teaching and Teacher Education, 36(0), 23-32. Retrieved from http://www.sciencedirect.com/science/article/pii/S0742051X13001005

Goh, P. S., \& Matthews, B. (2011). Listening to the concerns of student teachers in Malaysia during teaching practice. Australian Journal of Teacher Education, 36(3), 91-103.

Grow, L. P. (2011). The identity development of preservice teachers of literacy in field experiences considering their prior knowledge. (PH.D). University of Kentucky,

Hamman, D., Gosselin, K., Romano, J., \& Bunuan, R. (2010). Using possible-selves theory to understand the identity development of new teachers. Teaching and Teacher Education, 26(7), 1349-1361.

Harun, R. N. S. R. (2019). The construction and reconstruction of ESL student teachers' professional identity. Studies in English Language and Education, 6(1), 1-12.

Hattie, J., \& Timperley, H. (2007). The power of feedback. Review of educational research, 77(1), 81-112. 
Arab World English Journal (AWEJ) Volume 12. Number 1. March 2021

Uncovering New Paths to Adaptation: A Case Study of Malaysian

El Masry \& Alzaanin

Ibarra, H. (1999). Provisional Selves: Experimenting with Image and Identity in Professional Adaptation. Administrative Science Quarterly, 44(4), 764-791. Retrieved from http://www.jstor.org/stable/2667055

Ismail, S. A. A. (2011). Student teachers' microteaching experiences in a pre-service English teacher education program. Journal of Language Teaching and Research, 2(5), 1043 1051.

Izadinia, M. (2013). Areview of research on student teachers' professional identity. British Educational Research Journal, 39(4), 694-713.

Jamil, H., Abd. Razak, N., Raju, R., \& Mohamed, A. R. (2011). Teacher professional development in malaysia : Issues and challenges. CICE Series, 4(2), 85-102.

Kayi-Aydar, H. (2015). Teacher agency, positioning, and English language learners: Voices of pre-service classroom teachers. Teaching and Teacher Education, 45(0), 94-103. Retrieved from http://www.sciencedirect.com/science/article/pii/S0742051X14001267

Khalid, F. (2014). The impact of teaching practice experience in shaping pre-service teachers' professional identities. Mediterranean Journal Of Social Sciences, 5(20), 1921-1927.

Korkko, M., Kyro-Ammala, O., \& Turunen, T. (2016). Professional development through reflection in teacher education. Teaching and Teacher Education, 55, 198-206. Retrieved from http://www.sciencedirect.com/science/article/pii/S0742051X16300142

Ledger, S., Ersozlu, Z., \& Fischetti, J. (2019). Preservice teachers' confidence and preferred teaching strategies using TeachLivE ${ }^{\mathrm{TM}}$ virtual learning environment: A two-step cluster analysis. EURASIA Journal of Mathematics, Science and Technology Education, 15(3), em1674.

Lortie, D. (1975). Schoolteacher: A Sociological Study. London: University of Chicago Press.

Maaranen, K., \& Stenberg, K. (2020). Making beliefs explicit-student teachers' identity development through personal practical theories. Journal of Education for Teaching, 115.

Malaysia Education Blueprint 2013 - 2025: Executive Summary. (2012). Malaysia

Merriam, S. B. (2009). Qualitative research : A guide to design and implementation (2nd ed.). San Francisco, Calif.: Jossey-Bass.

Miller, K., \& Shifflet, R. (2016). How memories of school inform preservice teachers' feared and desired selves as teachers. Teaching and Teacher Education, 53, 20-29. Retrieved from http://www.sciencedirect.com/science/article/pii/S0742051X15300111

Ogeyik, M. C. (2009). Attitudes of the student teachers in English language teaching programs towards microteaching technique. English Language Teaching, 2(3), 205.

Olsen, B. (2008). How Reasons for Entry into the Profession Illuminate Teacher Identity Development. Teacher Education Quarterly, 35(3), 23-40. Retrieved from http://search.proquest.com/docview/222852280?accountid=28930

Oruç, N. (2013). Early Teacher Identity Development. Procedia - Social and Behavioral Sciences, 70(0), 207-212. Retrieved from http://www.sciencedirect.com/science/article/pii/S1877042813000578

Ronfeldt, M., \& Grossman, P. (2008). Becoming a Professional: Experimenting with Possible Selves in Professional Preparation. Teacher Education Quarterly, 35(3), 41-60. Retrieved from http://search.proquest.com/docview/222850909?accountid=28930

Saldana, J. (2009). The coding manual for qualitative researchers. London: Sage Publications Ltd. 
Salinas, D., \& Ayala, M. (2018). EFL student-teachers' identity construction: A case study in Chile. How, 25(1), 33-49.

Shafer, D. J. (2015). Preservice teacher understanding and implementation of caring teachinglearning student relationships. (PhD). University of Nebraska - Lincoln, (58)

Starkey, L., \& Rawlins, P. L. C. (2011). Teaching practicum in 21st century New Zealand: Ako Aotearoa.

Sueb, R. (2013). Pre-service Teachers' Classroom Management in Secondary School: Managing for Success in Teaching and Learning. Procedia - Social and Behavioral Sciences, 90, 670-676. doi:http://dx.doi.org/10.1016/j.sbspro.2013.07.139

Timoštšuk, I., \& Ugaste, A. (2010). Student teachers' professional identity. Teaching and Teacher Education, 26(8), 1563-1570. Retrieved from http://www.sciencedirect.com/science/article/pii/S0742051X10000880

Van der Wal-Maris, S., Beijaard, D., Schellings, G., \& Geldens, J. (2019). Exploring changes in student teachers' meaning-oriented learning. Journal of Education for Teaching, 45(2), $155-168$.

Wenger, E., McDermott, R. A., \& Snyder, W. (2002). Cultivating communities of practice: A guide to managing knowledge. USA: Harvard Business Press.

White, S. (2007). Investigating Effective Feedback Practices for Pre-service Teacher Education Students on Practicum. Teaching Education, 18(4), 299-311. doi:10.1080/10476210701687591

Yin, R. K. (2008). Case study research: Design and mthods (4th ed.). Thousand Oaks, CA: Sage. 